\title{
The Incidences of Kidnapping in An Urban Sprawl: Insights From White Sand, Lagos State, Nigeria.
}

\author{
Franca Attoh, PhD \\ Department of Sociology. University of Lagos \\ Emmanuel Fapetu \\ Department of Sociology. University of Lagos
}

\begin{abstract}
The focus of this study is the various incidences of kidnapping in one of the urban sprawls called White Sand in Ikotun/Igando in Alimosho Local Government, Lagos State, Nigeria. This is a qualitative study which involved indepth interviews with fifteen residents from the study location. The study hinged on Anomie theory and the Broken Window theory. The theoretical presupposition of the study is that given the prevalence of crime occasioned by the unequal access to legitimate opportunity in the society, urban sprawls without the presence of security apparatus are highly vulnerable to the invasion of criminals and in particular, kidnappers. The findings of the study revealed that absence of state security, unchecked incidence of minor crimes and the availability of easy route of escape were responsible for the invasion of the study location by kidnappers. The study also shows that anyone can be a victim of kidnapping and that collective effort by the community and security agents has the potency of stemming the tide of crime. The study therefore recommended that the government should ensure that police posts are established in all existing sprawls in the state and that the state's neighbourhood watch should be extended to the sprawls in order to protect them from criminal onslaughts.
\end{abstract}

Keywords: Incidence, Kidnapping, Urban, Urban Sprawl, Victim.

\section{INTRODUCTION}

Nigeria has been ravaged by several criminal activities since the post civil war era but the problem of kidnapping remained unattended to for a long time until recently. Kidnapping became a serious problem in recent time because almost everyone is vulnerable whether rich or poor both in the urban and rural areas of the country. The upsurge of Niger-Delta militancy contributed immensely to the emergence of kidnapping as major crime that threatens the fabrics of the society. Later, the menace spread to other parts of the country, making the country one of the hubs of kidnapping among the countries of the world. The problem of kidnapping has been reported in about twenty-two states of the federation in recent years (Ukoji \& Okolie-Osemene, 2016).

The incidence of kidnapping in Lagos state took a dramatic turn when the urban sprawl turned out to be the target of kidnapping gangs. The case of Evans, a notorious kidnapping gangster, in Lagos state was a major headline in all media platforms in the country. Major kidnapping incidences in Lagos state including the case of Evans occurred in the urban sprawls, making those in the urban sprawls more vulnerable to the crime. This may be as a result of the absence of security agents and the poor presence of enforcement agents in these areas despite the efforts of the state government to ensure the security of lives and property in the state. The questions that come to the fore here are as follows. How vulnerable are the urban sprawls in Lagos state to the incidence of kidnapping? Who is liable to be a victim of kidnapping in the 
sprawls? What are the effects on the urban sprawls? How do the urban sprawls respond to the incidence of kidnapping? And what measures are the sprawl communities putting in place to prevent the incidence of kidnapping? In the light of the foregoing, this paper focuses on the incidence of kidnapping at White Sand, an urban sprawl in Alimosho Local Government Area of Lagos state.

\section{STATEMENT OF THE PROBLEM}

Nigeria is currently bedeviled by numerous criminal activities both violent and non-violent. Notable among these crimes is the upsurge in kidnapping for ransom which has ravaged the country creating an atmosphere of fear, anxiety, suspicion and general sense of insecurity. The incidence of kidnapping has got to the level where anyone can fall victim thereby increasing the loss of confidence reposed in the state security apparatus. The surge of kidnapping in the wake of incessant killings by criminal and terrorist groups in Nigeria has made the country one of the most dangerous places in the world. In Nigeria, Lagos state government has been applauded for its many security programmes and strategies which have resulted in the general reduction of crime in the state but the scourge of kidnapping in the state tends to undermine the efforts of the government. Most of the strategies put in place by Lagos state government to ensure the safety of lives and property have excluded the Urban sprawl. The Urban sprawls in Lagos state house a significant proportion of the state's population, therefore their exclusion from the security plans renders them vulnerable to criminal onslaught like kidnapping. This study therefore is concerned with the incidences of kidnapping in one of the Urban sprawl in the state.

\section{DEFINITION OF CONCEPTS}

Incidence refers to the extent to which an event occurs. The incidence of kidnapping is therefore, the extent to which kidnapping occurs in and affect a particular area.

Kidnapping can be defined as forceful seizure of a human being, kept in custody in an unknown location with the aim of obtaining financial/economic or political or socio-cultural gains. It is a form of robbery involving human being as the stolen object.

Urban refers to a geographical location having all the characteristics of a town or city.

Urban Sprawl is an unplanned expansion of a city or town into the countryside. It is a large settlement that evolves into the countryside as a result of population pressure in the town or city.

\section{REVIEW OF LITERATURE HISTORY OF KIDNAPPING}

Kidnapping is an old practice in different parts of the world with varying motives. The concept of kidnapping was earlier used in 1673 in American colonies for the practice of stealing children for use as servants or labourers (Ngwama, 2014). Also, in England of the 17th century, children were kidnapped and sold as slaves or agricultural workers to colonial farmers. Prior to that Era, the Roman Empire witnessed the scourge of kidnapping that caught the attention of Emperor Constantine in $315 \mathrm{AD}$ to impose a death sentence on whoever was guilty of kidnapping (Ottuh \& Aitufe, 2014). Several countries such as Colombia, Haiti, Philippines, Iraq and Mexico have witnessed serious kidnapping incidences such that they have been rated as kidnapping hubs of the world. It was not a common practice in Africa except in South Sudan where kidnapping was a means of obtaining slaves or money through ransom (Ilechukwu, Uchem \& Asogwa, 2015). Africa's share of global kidnapping incidence has increased over the years owing to political crises, terrorism and insurgency. Figure 1 below shows that Africa 
shared $34 \%$ of global kidnapping incidence, second behind Asia which had $40 \%$ of total kidnapping incidence.

Figure 1: Global Kidnapping Incidence by Region, 2015

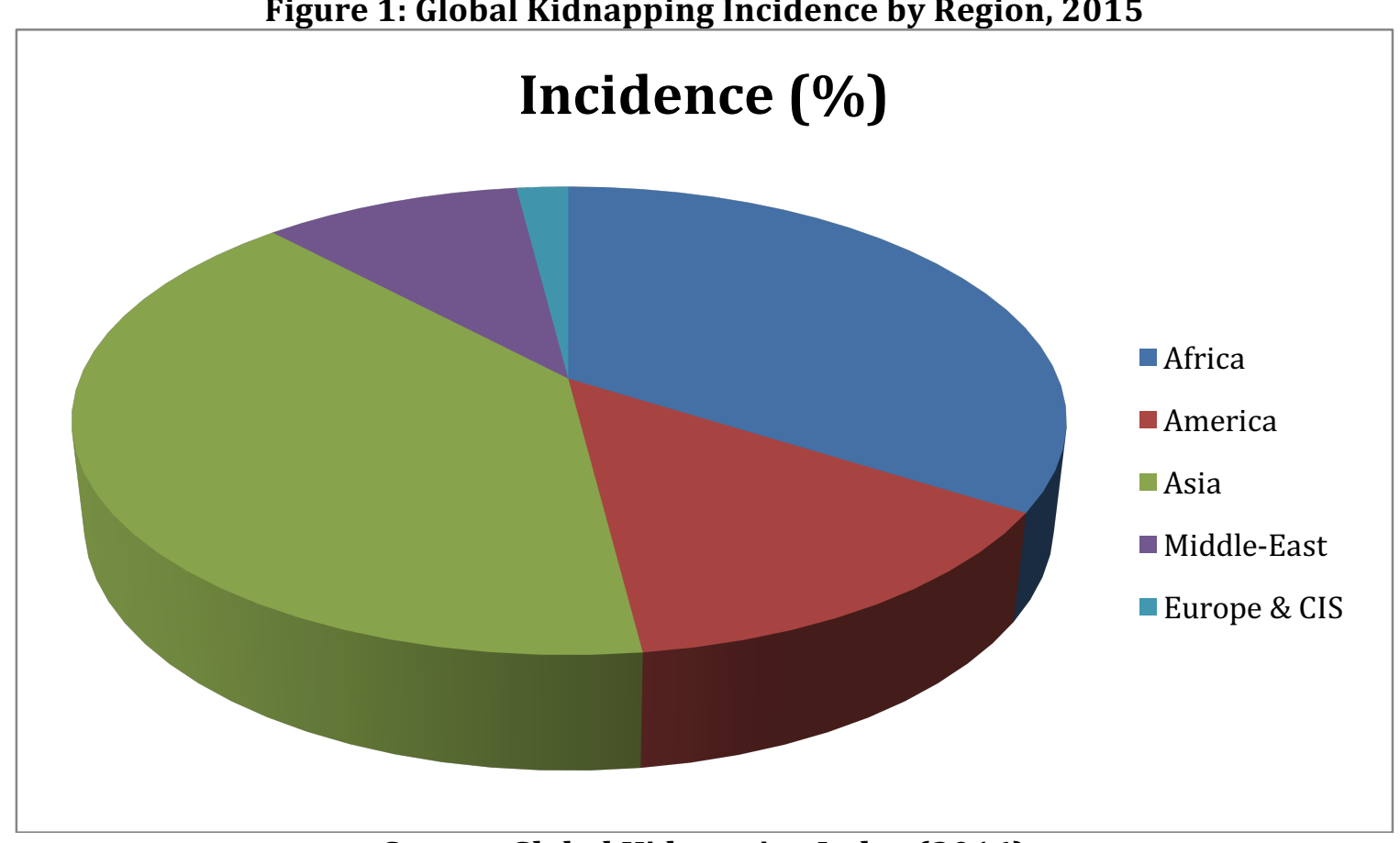

Source: Global Kidnapping Index (2016)

Prior to the crisis in the Niger-Delta, kidnapping was known as an instrument in the hands of ritualists to get human persons (especially children) for their ritual purpose. Kidnapping was not really conceived as a major threat to peace and security. The Niger-Delta militants took kidnapping to a new dimension when they started kidnapping oil workers especially expatriates for ransom, as a means of getting the attention of the government and the international community to their agitation over the deplorable state of the Niger-Delta region. As the incidence of kidnapping subsided in the Niger-Delta region, the unemployed youths in the eastern region adopted it as a business from which they could make ends means (Okoli \& Agada, 2014). As the economy declined in 2016, middle and lower class people became the target of the kidnapping groups to generate some money. From there, almost every part of the country has witnessed the scourge of kidnapping to the extent that Boko-Haram adopted it as an operational strategy for major mass abductions of school children in north-eastern Nigeria. Moreover, a significant number of kidnapping has been recorded in Lagos state in the past five years, involving both children and adults of different social status. For instance, 11 students and their teacher were kidnapped and released after the payment of ransom in late 2016 . The case of Evans, a kidnapping gangster, still remains fresh in the memory of the residents of Lagos. However, Lagos State Government strengthened the penalty for kidnapping in 2017. Kidnapping now attracts life sentence and if the victim is found dead, the convict is liable to death sentence (OSAC, 2017).

\section{TYPES OF KIDNAPPING}

Criminal Kidnapping is a form of kidnapping carried out by a criminal group for the purpose of getting monetary benefits from the victim's family, business or associates. The perpetrators can be seen as businessmen who seek economic gain through the business of kidnapping, though an illegal activity (Ilechukwu, Uchem \& Asogwa, 2015). This kind of kidnapping also involves kidnapping for the purpose of robbery, extortion, influencing business decision, obtaining commercial advantage, recovery of debt and to secure advantage in a criminal 
market (Ottuh \& Aitufe, 2014; Okoli \& Agada, 2014). In Nigeria, there are even cases of stagemanaged kidnapping where people colluded with kidnappers to stage their own abduction with the intent to share the ransom with the supposed kidnappers (NewsAdmin, 2013).

Political Kidnapping is often carried out for the purpose of advancing a political cause. The use of kidnapping by the Niger-Delta militants as well as Boko-Haram in Nigeria is aimed at achieving political objectives. While the militants used it as one of the means of expressing displeasure over the marginalization of the Niger-Delta region, the Islamic sect (Boko-Haram) used it as an instrument of aggression to foster their quest for an Islamic state (Okoli \& Agada, 2014). In other parts of the world, kidnapping has been used to settle political scores, a situation where a rebel group kidnaps an important figure in the political sphere in order to get a political agreement from the ruling class. Kidnapping is also used as an ideological instrument where ideological conflict is occurring (Ottuh \& Aitufe, 2014). Kidnapping is, moreover, used in some instances by politicians to suppress, intimidate, outsmart and subjugate political opponents. For instance, the kidnapping of the father of Charles Soludo (former Central Bank Governor), the PDP gubernatorial candidate by aggrieved opponents in the party over their marginalization in the party's political process (Ngwama, 2014).

Pathological Kidnapping refers to a kind of kidnapping carried out by people who are emotionally disturbed. This may involve the abduction of a woman for the purpose of raping her. In some African societies, kidnapping was used as a means of perpetuating forced marriage. In this case, a bride or bridegroom is abducted without his/her parents consent to an unknown destination to enforce marriage against the will of the parents (Okoli \& Agada, 2014).

\section{VICTIMS OF KIDNAPPING IN NIGERIA}

In Nigeria, the possibility of an individual being kidnapped depends on his/her social class, economic, cultural and symbolic capital among others. According to the Immigration and Refugee Board of Canada (2014), people targeted for ransom kidnapping include, high profile Nigerians and their family members, Foreign nationals and expatriates, wealthy families, politicians, professors and their families, government officials, celebrities and their relatives, businessmen and companies' directors/executives, doctors, teachers, foreign residents and religious leaders.

\section{EFFECTS OF KIDNAPPING}

Economic Effects: The incidence of kidnapping affects the economy at the individual, community and state levels. While the victims of kidnapping lose financially by paying ransom to kidnappers in order to gain freedom, the community may be forced to spend money in the employment of private security guards to protect the community. Widespread kidnapping incidence in any given state may force the government to increase its spending on security rather than increasing spending on development (Inyang \& Ubong, 2013). Also, kidnapping scares both local and foreign investors from investing in the country thereby contributing to the rate of unemployment (Ottuh \& Aitufe, 2014).

Socio-Psychological Effects: Kidnapping affects the psychological wellbeing of the victim as he may suffer from the trauma for a long time. Social activities may be impeded due to the fear of being kidnapped, as mutual suspicion trails social relations and movement at particular period of time in the day becomes difficult. Also, kidnapping contributes to the waning of public trust in the state security agents and the image of the country in the international community tends to be tainted (Inyang \& Ubong, 2013; Okoli \& Agada, 2014 ; Ilechukwu, Uchem \& Asogwa, 2015 ) 


\section{THEORETICAL UNDERPINNING}

The menace of kidnapping in Nigeria can be situated within two theoretical exposition, Anomie and Broken Window theories.

The Anomie theory as espoused by Robert K. Merton views the involvement of members of the society in criminal activities as a response to unequal distribution of opportunity in the society, especially in societies driven by success goals. According to Merton, the society sets success goals for all members as well as legitimate means of achieving them, but the social structure does not provide equal access to the legitimate means. Therefore, individuals not favoured tend to respond in the following ways.

Conformism: Individuals in this category uphold the goals and the legitimate means despite unequal access to legitimate opportunity.

Ritualism: This category of people rejects the success goal but holds on to the legitimate means. Innovation: The individuals in this group believe they can achieve the success goals but reject the legitimate means and develop an illegitimate means to achieve the goals.

Retreatism: This group of individuals reject both the goals and the means but resort to a life of isolation, drug addiction and alcoholism.

Rebellion: People in this category reject both the goals and the means but develop new goals and means which run contrary to that of the society.

The Niger-Delta militants and Boko-Haram can be classified as rebellious because they hold goals which are contrary to the status quo and develop their own means of achieving their goals, one of which is kidnapping. But the rapid proliferation of kidnapping gangs in Nigeria today is an innovative response to unequal access to legitimate opportunity. Given the high rate of unemployment, poverty and increasing economic hardship in the country, many young people see kidnapping for ransom as a lucrative business through which they can make ends means and eventually achieve financial and material success which provides the opportunity to climb up the social ladder.

Broken Window Theory of Wilson and Kelling (1982) explains the signaling effect of urban disorder. The theory posits that serious crimes occur in urban communities as a result of community negligence in dealing with less serious crimes like theft and vandalism. This negligence encourages criminals to venture into more serious crimes and this makes the community more vulnerable to notorious crimes. It also suggests that the strategy for preventing serious crime in the urban community is to deal with the problem of vandalism and other petty crime when they are still small. Urban sprawls in Lagos are open to so many petty criminal activities like theft and vandalism due to the availability of many escape routes and less security presence. Being newly developing areas of the cities, people tend to be less integrated owing to the fact that they got into the area from different places, until the petty crimes degenerate into life threatening crimes like assassination, armed robbery and kidnapping. Therefore, urban sprawls in Lagos are more vulnerable to kidnapping incidence than the main cities.

\section{METHOD}

The study adopted a non-experimental design, with the collection of qualitative data through indepth interview from 15 residents of the study area who were house owners. House owners 
were used in this study because most of the residents own their own houses. The collected data were analysed using content analysis.

\section{STUDY LOCATION}

White Sand as an urban sprawl is located at Ijegun, in Alimosho Local Government Area of Lagos state. It is a residential community that grew gradually from 2003 as a result of increasing movement of people from the main urban centres in Lagos state to Ijegun. The location is called white sand because the earliest occupants occupied the part of the area basically characterised by white soil (sand). The area is more of swampy vegetation like the surrounding settlements. White Sand is bounded by Ijegun, Isheri-Oshun and FESTAC Extension

\section{ANALYSIS OF FINDINGS}

\section{Socio-Demographic Characteristics of Respondents}

\begin{tabular}{|c|c|c|}
\hline Age & Frequency & Percentage \\
\hline $20-29$ & 3 & 20.0 \\
\hline $30-39$ & 6 & 40.0 \\
\hline $40-49$ & 5 & 33.3 \\
\hline $50-59$ & 1 & 6.7 \\
\hline Total & 15 & 100 \\
\hline Sex & Frequency & Percentage \\
\hline Male & 6 & 40.0 \\
\hline Female & 9 & 60.0 \\
\hline Total & 15 & 100 \\
\hline Marital Status & Frequency & Percentage \\
\hline Single & 2 & 13.3 \\
\hline Married & 13 & 86.7 \\
\hline Total & 15 & 100 \\
\hline Education & Frequency & Percentage \\
\hline Primary & 2 & 13.3 \\
\hline Secondary & 7 & 46.7 \\
\hline Tertiary & 6 & 40.0 \\
\hline Total & 15 & 100 \\
\hline Ethnic Group & Frequency & Percentage \\
\hline Igbo & 3 & 20.0 \\
\hline Yoruba & 8 & 53.3 \\
\hline Others & 4 & 26.7 \\
\hline Total & 15 & 100 \\
\hline Religion & Frequency & Percentage \\
\hline Christianity & 10 & 66.7 \\
\hline Islam & 5 & 33.3 \\
\hline Total & 15 & 100 \\
\hline
\end{tabular}

Source: Fieldwork (2018). 
The table above shows that $20 \%$ of respondents were within age $20-29,40 \%$ of the respondents were within 30-39 years, 33.3\% of respondents were within 40-49 years and $6.7 \%$ of respondents were within $50-59$ years. The average age of respondents is 37 years. Also from the table, $40 \%$ of respondents were male while $60 \%$ of the respondents were female. The table shows that $13.3 \%$ of respondents were not married while $86.7 \%$ of the respondents were female. This shows that most respondents were married. Concerning the educational level of respondents, the table shows that $13.3 \%$ of respondents were primary school leavers, $46.7 \%$ of the respondents had secondary education, while $40 \%$ of the respondents had tertiary education. This reveals that a greater number of respondents had at least secondary school education. Moreover, $20 \%$ of respondents were from Igbo ethnic group, $53.3 \%$ of the respondents were from the Yoruba ethnic group while $26.7 \%$ of the respondents were from other ethnic groups specifically from the south-south region. This means that majority of the respondents were from Yoruba ethnic group. Finally, the table shows that $66.7 \%$ of respondents were Christians while $33.3 \%$ of the respondents were Muslims. This means that majority of respondents were Christians.

\section{Vulnerability of Urban Sprawl to Kidnapping}

Urban sprawls in Lagos state are highly vulnerable to the incidence of kidnapping owing to the fact that they are open and can be accessed by criminals easily without any form of restriction. Findings from the study locations show that the kidnappers could perpetrate the crime due to the porosity of the area. There are routes through which they can get into the area and escape easily despite their use of arms in carrying out their operation. This was emphasized by one of the respondents thus,

'You know, in every new site, there must be challenges. Eeh, when we first came here, the challenges we face here is about either two years ago. The challenge we face is there are kidnappers everywhere. It is all these new sites that kidnappers always go to operate because there are bush, swamp and other places where they can follow to do their evil work' (Respondent 13, Male).

Another respected said,

'........this is their major route, they pass here to come into this environment to kidnap some people, especially, owners of houses they think could pay their ransom. So, it's a very big problem because I will say it's very close to a big forest, like am just coming from there, I just said I should take a look, but bush still have to push me back, but they have their own way. I don't know how they maneuver their way through' (Respondent 1, Male).

Another respondent also said,

'......tori igbakan, wahala wa nibi, toje pe, lets say last year won bere si ni kidnappu awon eeyan tori ona wa yi ti jade si FESTAC, nigba to de ti jade si FESTAC, awon kidnapper wole' (Respondent 6, Female).

Translation:

Because sometimes ago, there was a serious problem here, lets say last year, when they started kidnapping people here. This happened because this area is now linked to FESTAC. So, kidnappers could find their way into this place.

Another respondent reiterated thus,

'Those sides link to FESTAC, they come from FESTAC side. When they kidnap people, they take that route back because the road is bad, it's not motorable, they use 'Okada' to pass that route' (Respondent 8 , Female). 
To further establish this fact, another respondent echoed,

'Awon na o gba titi wole, eyin ilu ni won gba wole. FESTAC extension ni won gba wole, because gbogbo ibeyen swamp area ni, tori awon ti won mu, awon marun niwon kidnap nigbayen, inu igbo ni won wo won gba nigbayen lohun' (Respondent 9, Male).

Translation:

They did not come in through normal route; they came in through the outskirt. They came in through FESTAC extension, because that area is a swamp and they escaped with those kidnapped through the same route. Five people were kidnapped and were dragged through the bush over there.

Figure 2: Showing the Kidnappers' Route at White Sand

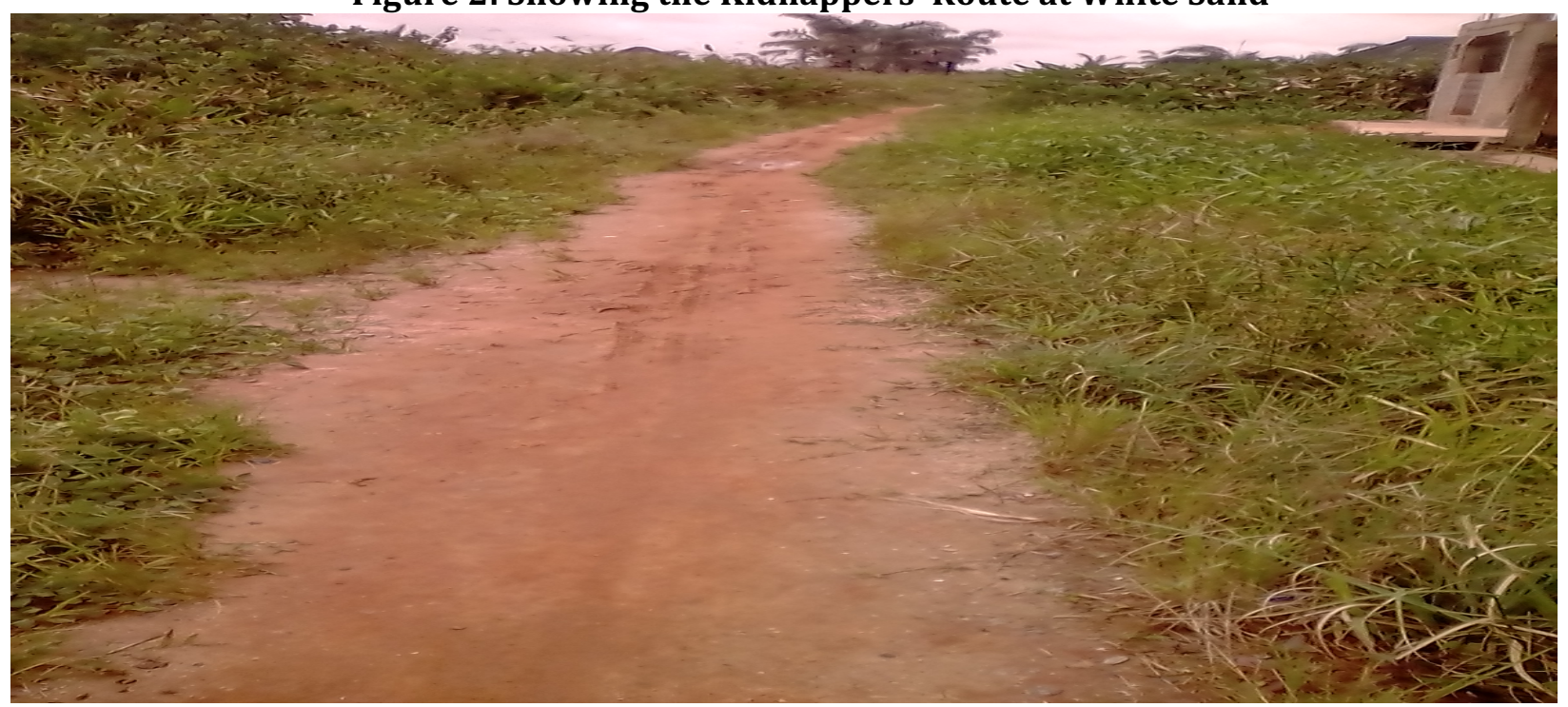

Source: Fieldwork (2018).

Figure 3: Showing the Inner Part of the Kidnapper's Route at White Sand

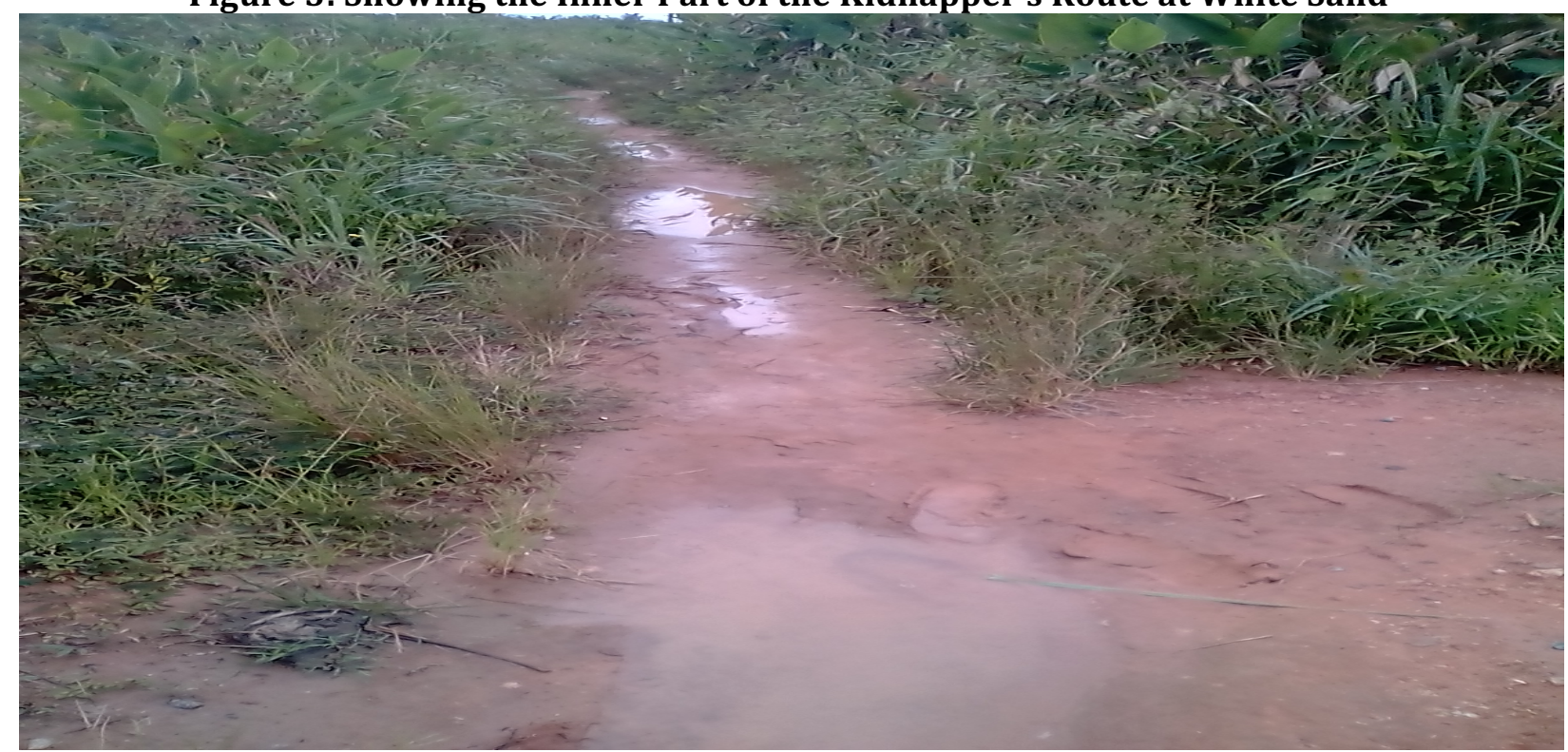

Source: Fieldwork (2018).

This attests to the fact that the study location was highly vulnerable to kidnappers' onslaught. However, the vulnerability of the area to kidnapping is further evident in the occurrence of different less serious or minor crimes which could have given the kidnappers the confidence to enter the area. This was raised by one of the respondents, 
'Before, we use to have security issues like people burgling into the house, especially on Sundays; you know everywhere will be quiet. During the church hour, they do burgle peoples' house and steal stuffs. It has reduced now. But then, we were having issues in the night, they come, they burgle cars and take away spare parts from the cars, but it has reduced now' (Respondent 8 , Female).

Another respondent said,

'Aside the kidnapping aspect, there is no record of armed robber except these minor minor stealing' (Respondent 1, Male).

Another fact that makes urban sprawl vulnerable to crime like kidnapping is the absence of state security agencies there, especially the police. There is total absence of the presence of the police in the study location, such that no single police post has been stationed there. The nearest police station to the area is very far away from the area, thereby making it easy for kidnapper to enter and exit the area without fear. One of the respondents said, '......... when somebody is crying for help, because police post is far away from here, the nearest police post is at Isheri' (Respondent 1, Male).

\section{Victimisation and the Timing of Kidnapping}

Criminal groups often operate at a predetermined time when they can easily get their targeted prey. In the same vein kidnappers usually target particular times when they can have easy access to their victims and easy escape from being apprehended. Findings from the study location show that the kidnappers operated between $6.00 \mathrm{pm}$ and $8.00 \mathrm{pm}$ when people were just coming from their various places of work to rest from the hustle and bustle of work for the day. This fact was echoed by one of the respondent thus,

'Ko n sosan, ko nsoru, but bii around six irole lo soke ni won maa n sise yen. Tori ijo ti won ko bere ise yen, niwaju mi nbibayi ni. Iyawo eni to ni ile yi ni won koko gbe nigba yen. Time yen, even gan, ko pe ti awa gan kuro nibiyi ti a wole bi around six-thirty ni won sise tijo yen ko to dipe won wan se awon ise yen kaakiri kaakiri' (Respondent 2, Female).

Translation:

It was neither in the day nor in the night, it was in the evening from six upward. The first incidence happened in my presence here. The first victim of the incidence was the wife of the owner of this house here. At that time, the incidence occurred around sixthirty in the evening, just a few minutes after we went into our own house. From then, they started kidnapping people everywhere.

Another respondent said,

'Won maa n sise si six irole, won de maa n sise ni six si eight lale' (Respondent 4, Female).

Translation:

They normally kidnap people between six in the evening and eight O'clock.

Another respondent reiterated thus,

'Won le ti harbour ara won si inu igbo bii six O'clock, a di bi nkan bi eight O'clock yen, eko maa gbo pe won ti wa, ko seni to maa mo ibi ti won wa gan an' (Respondent 9, Male). 
Translation:

They would have laid ambush in the bush around six O'clock and by eight O'clock, you will hear that they have come but you would not know where they were actually.

Concerning the victims of kidnapping in the study location, no specific category of person was identified as target of the kidnappers. Respondents reported that the kidnappers abducted whoever was unfortunate to fall prey to them. This was emphasized by one of the respondent thus,

'There is no specific category of person they kidnapped; it's just anybody that is just unfortunate to fall in their trap' (Respondent 8, Female).

Another respondent said,

'People were saying that they know the people they want to carry, that it's the rich men, may be they did business together, we cannot say per se' (Respondent 15, Female).

Moreover, one of the respondents gave a clue about some actual victims of the kidnapping incidence in the study location. He informed that,

'Oro te so yen, oro nla ni, oro oni kidnapper ti e so yen, in fact, a lose eeyan meji, C.P gan wa lati wo scene yen. Eyan meji ni won pa, chairman CDA(harmony) and man egun kan ni won pa..........................., two streets si ibi ti a ti $n$ soro ni won ti wa mu Alfa White, Oloso side, ibe ni won pa eyan si ni igbayen' (Respondent 9, Male).

Translation:

The kidnapping incidence you are talking about is a serious one; in fact, we lost two people that the commissioner of police himself came to the scene to confirm. The two people kidnapped were, a CDA chairman (Harmony) and an Egun man...... Alfa White was kidnapped two street from here while those killed were murdered at Oloso side.

However, the same respondent revealed that no kidnapper was arrested during the period of the mayhem. He said,

'Ao gbo pe won ri won mu, afi igba ti a gbo pe won mu notorious kidnapper, Evans, ni Ikeja abi Magodo, lati igba yen, a ri pe oro kidnapper wole' (Respondent 9, Male).

Translation:

We never heard that anybody was arrested, aside the arrest of Evans, a notorious kidnapper at Ikeja or Magodo. Since then, kidnapping incidence has subsided.

\section{Effects of the Incidence on the Community}

Criminal activities often affect the fabrics of the society in different ways, which may range from economic, social to psychological effects.

\section{Psychological Effect}

The incidence of kidnapping in the study area created an atmosphere of fear and suspicion among members of the community. The situation was so serious that people found it difficult to move freely in the area as they were used to prior to the invasion of the community by kidnappers. One of the respondents said,

'The effect of the kidnapping was fear and it discouraged people from moving in

so it has reduced trust' (Respondent 1, Male). 
Another respondent said,

'Se e mo, nkan ti eeyan o ba ri ri, o maa n serubayan pupo' (Respondent 2, Female).

Translation:

You know, what one has not experience before will definitely make one afraid

Another respondent added,

'It affect us much. As we are sitting now, we could not sit, seeh when you here 'gbogbo-gbo-gbo' you will be able to sit. Eeh eeh, okunrin yi o ti mo nkankan(this man does not know anything). Although, I was not born when they were fighting the civil war, but eem, the one I see.....' (Respondent 3, Female).

Another respondent said,

'Well, it wasn't funny honestly, they kidnap people demanding that for ridiculous amount of ransom, it go on like 3 months, we could not walk freely, everybody was scared......' (Respondent 8, Female).

Another respondent further claimed that,

'......toba ti di irole, onikaluku a ti wole, a ti ilekun mori tori awon kidnapper to won gbe awon eyan' (Respondent 12, Male).

Translation:

In the evening, individuals would have stayed indoors and lock their doors because of the kidnappers at that time.

Another respondent also said,

'....to the extent that most of the people living in the neighbourhood moved away to sleep somewhere else' (Respondent 13, Male).

Another respondent reiterated,

It really affect us oh, because by then, before we come out in the morning, it will be around 7 O'clock and in the night in the evening by 7.00 pm, everybody would have gone in' (Respondent 15, Female).

Another respondent added,

'Like in the after time when everywhere is so quiet, in the evening time, there is a place called 'Oninuwari', you cannot cross that place because in near canal inside that place, so, nobody fit pass the road at that time because of eem' (Respondent 5, Male).

\section{Developmental and Social Effect}

Given the extent of fear and suspicious atmosphere created by kidnapping incidence in the study location, the pace of development in the area reduced drastically. This was a result of the abandonment of the area by many residents and house owners to the extent that many refused to return after the incidence had subsided and some who were developing their property had to abandon them or even sold them off. This reduced the population of the area and consequently made social life less interesting. One of the respondents echoed this fact in the following words.

'You see, this house has been like this for over two years the same way and I'm sure it's not about money that kept them away. You know, some people abandoned their houses and fled. So, it discouraged people from working on their property or building 
and discouraged some people from packing into the environment' (Respondent 1, Male).

Another respondent narrated,

'...tori awa bi enikan, a kuro ladugbo yi, awa kuro, opolopo eniyan na ni won lo de bi pe, opolopo no o pada wa; eniti o maa ta ile ta ile, tori won nipe awon o le pada wa gbe ibiyi mo' (Respondent 2, Female).

Translation:

Even we as persons left this community together with many other people who refused to return; some sold their houses because they were afraid of returning to live here again.

Another respondent said,

'I ran to my village. Some people traveled out, till today, they have not come back; some rent their house to people and run back to the town' (Respondent 3, Female).

Another respondent said,

'In fact, emi gan ti mo n bayin soro yi gan, o ti to time ti mo fe move out kuro nibibayi. Awon kan ti move out pelu iyawo ati omo won, emi kan lawa kan fi duro pe, se a wa fe fi ile wa sile ni?' (Respondent 9, Male).

Translation:

In fact, I as a person had concluded that it was high time I moved away from here. Some people moved out with their wives and children. We just encouraged ourselves that, shall we leave our house because of the incidence?

Another respondent reiterated,

'....some people run, even many landlord self run comot, den leave their house and run comot' (Respondent 11, Female).

In addition, one of the respondents pointed out that business activities were also affected by the kidnapping incidence. She said,

'You cannot come and do business here, eeh, may God help us oh' (Respondent 3, Female).

\section{Community Response to the Kidnapping Incidence}

Every human community has the responsibility of protecting its members from any form of danger or events that risk the lives of its members. The failure of any community to take drastic step capable of warding off criminals from its domain will give criminals the opportunity to overtake and terrorise it. In the study location, the Community Development Association (CDA) responded to the incidence of kidnapping by contacting the local government authority and the state government as well as the police to come to their rescue. The government and the police responded to the distress call by deploying policemen and some soldiers to the community to deal with the menace. This fact was revealed by one of the respondents in the following words.

'The community alerted the government which gave security eem, all these mobile police. This container was their base, they were there and secure this environment for several months and ensure there was no incidence like that again' (Respondent 1, Male). 
Another respondent said, '.....awon taa fi se olori ni won se ise yen tolorun fi ko sokan awon to wa nijoba ti won fi send awon soja yen........won ko awon soja wa ti won bawa sise ti won si duro ti wa ni gbogbo igba yen titi ti olorun fi bawa tiwon lo' (Respondent 2, Female).

Translation:

Those we appointed as community leaders took the responsibility upon themselves before God used those in the government to send soldiers here. The soldiers who were sent here stood by us till the incidence was eliminated.

Another respondent said,

'It's God, and wa cried to the state government, he now sent mobile police and army to this place to guard everywhere, there coming and going' (Respondent 3, Female).

Another respondent reiterated,

'Won mu awon mopol wa. Chief kini wa, o mu awon mopol wa. Oru ni won ko won si joint by joint titi ti gbogbo e fi die down' (Respondent 4, Female).

Translation:

Our chief leader brought mobile police. They were brought into this area in the night and assigned to specific spots till the incident subsided.

Another respondent explained,

'The police came but actually, this is not the duty of police. After that time oh, the army and mopol enter this place. When army entering this place, so, all of them let because they are carrying more weapons' (Respondent 5, Male).

Another respondent corroborated thus,

'Adugbo, won try gan. If not because of awon landlord association, wahala iba si wa nibi. Awon landlord wa, they are very very good, they are very powerful, won se a lot of things. Igbese ti won gbe nipe, won lo si local government, won lo report. Awon soja wa wole lati je ki gbogbo wahala yen ko dopin. Iru ibi ti won gba wole yen, won ni lati gbe awon soja sibe' (Respondent 6, Female).

Translation:

The community really tried. If not because of the efforts of the Landlord Association, the incidence would have continued. Our landlords tried, they were very good; they were very powerful; they did a lot of things. The step they took is that they reported the problem to the Local Government Authority. Soldiers came here to ensure that the problem was put to an end. Soldiers were deployed to the route of the kidnappers.

Another respondent said,

'Thank God pe a ni governor leko, a fi igbayi dupe lowo governor Ambode. Emi ti mo $n$ ba yin soro, a jo lo salausa ni lati lo protest ni , a si dupe pe won wa rescue wa...... Olopa try a lot o, Isheri police station ati Area Command lati Idimu won sise' (Respondent 9, Male).

Translation:

Thank God that we have a governor in Lagos; we use this opportunity to thank Governor Ambode. I was one of those who went on a protest to Alausa and we thank 
God that they came to our rescue. The police tried a lot, especially Isheri police station and Idimu Area Command.

Another respondent reiterated,

'They really tried then, they went to Alausa to complain and they gave them some policemen, the mopol. They were all around this place. There are still some around here. There are still some mopol, if you go to FESTAC side, you will see them, even Alausa and Iwa side, you will see them' (Respondent 15, Female).

However, the success of the police and the military in rescuing the community from the invasion of kidnappers was not without the support of the members of the community. The community provided places for them where they could use as shelter, materials like torch which could aid their activities in the night as well as moral support. One respondent narrated,

'...the community is still contributing, you know, they are on special duty, the community provide small place for them to stay, buy torch for them and everything' (Respondent 3, Female).

Another respondent said,

'A little na ti won lese, in fact, won gbiyanju. A ni central CDA, nigba wahala yen, chairman central CDA funra re a jade ni oru lati lo baa won olopa, iyen Pastor Adewale Oyewo, pelu awon security ti won $n$ lo kaakiri. In fact, o gbiyanju' (Respondent 9, Male).

\section{Translation:}

They did the little they could do. In fact, they tried. We have a central CDA (Community Development Association). During that period, the chairman of the central CDA himself used to go round in the night to meet the police. That is, Pastor Adewale Oyewo with some security men. In fact, he tried.

Moreover, the community also involved non-governmental security bodies to assist the police and the military in the effort at saving the community from the menace of kidnapping. One respondent said,

'And again these people around taking care of the environment, these people called 'Ayewo' and 'Omo Onile', so they helped' (Respondent 1, Male).

\section{Community Measures to Prevent Future Incidence}

The post-kidnapping era in the study area has not witness the stationing of any police post or station but the community through the CDA has been able to provide security measures to prevent further occurrence of such serious crime. The community has been able to employ night guards, vigilante and other security outfits. This was echoed by one of the respondent thus,

'We have night guards, we have all these local security. It is only that when they find there is a case that a local security cannot handle, they will now cry to government again, government will now send force people to this place' (Respondent 3, Female).

Another respondent said,

'Onikaluku gba vigilante. Ni each each street, a ni vigilante to $n$ secure won' (Respondent 4, Female).

Translation:

Everybody employed vigilante. Each street has vigilante as its security. 
Another respondent corroborated that,

'Nigbati gbogbo iru won yen o si mo, won gba night guard to $n$ so street by street'

(Respondent 6, Female).

Translation:

After the incidence had stopped, they employed night guards that secure each street.

Moreover, another respondent revealed that a means of communicating security breaches has been put in place to prevent any form of crime from overtaking the community. The respondent said,

'There are many things being done. Now, there are telephone numbers that anywhere you can contact to relate if anything. Though, we the community have our own security which I cannot disclose to whoever is interviewing me' (Respondent 13, Male).

\section{DISCUSSION OF FINDINGS}

The incidence of kidnapping in Nigeria has been seen by many people as one of the most unfortunate crimes to have bedeviled the country in the $21^{\text {st }}$ century. Though, an old practice among ritualists in the country, the spread of kidnapping for ransom gradually spread to Lagos from other parts of the country, despite the security efforts of the state government. The incidence of kidnapping had occurred in several parts of Lagos in recent years and specifically in the urban sprawl like White Sand.

From the findings of this study reveals the fact that urban sprawls in Lagos state are more vulnerable to the incidence of kidnapping as a result of the porosity of the areas, consistent occurrence of several minor criminal activities unchecked and the absence of state security agencies. Urban sprawls are normally surrounded by bush which can serve as hide-outs and escape route for criminals. Since the sprawl appears a newly developing area, different kinds of people explore the area for different purposes and the absence of community sense among residents. The lack of community sense is based on the fact that most residents are new in the area and have not established a concrete social bond with one another. This renders the sprawl vulnerable to the menace of kidnapping. The findings also confirm that several minor criminal activities like theft and vandalism have been consistently witnessed by residents prior to the upsurge of kidnapping in the area. The free entry and free exit give criminals the opportunity to familiarize themselves with the sprawl, attempt several minor criminal activities to know the extent of success they are liable to make if they commit a serious crime. This fact corroborates the position of the Broken Window theory that when minor crimes are allowed unchecked in any community, serious crimes are more likely to be committed there. The porosity of urban sprawl in Lagos is further made worse by the absence of the various state security forces as evident in the study area. Most of the security forces in Lagos state, that is, the Police, State Anti-Robbery Squad (SARS), Neighbourhood Watch and the rest concentrate their activities in the main towns and cities, leaving the sprawls vulnerable to the invasion of criminals like kidnappers.

Criminals usually target specific time within which they could commit their crime and escape easily with the proceeds of the crime. The study shows that kidnappers often target a time when prospective victims are off-guard to carry out their dreaded act. In the study area, the kidnappers targeted the evening time when most people were just returning from work and tired from the work stress of the day, in order to find it easy to impose themselves on the victims. Also, the study shows that anybody can be a victim of kidnapping as emphasized in the literature. Given the fact that most residents of the study area are house owners, kidnappers 
are likely to view them as rich enough to pay their ransom, therefore, any resident of urban sprawl can fall prey to kidnappers.

The incidence of crime in any community over a period of time often create a sense of insecurity among people but the occurrence of kidnapping incidence tends to have a far reaching effect on the entire life of the residents of such community. The study area, as revealed in the study was overwhelmed by fear and suspicion as nobody could be trusted. Social and economic activities were truncated; freedom of movement was made almost impossible; and there was a general state of apprehension. This situation led to the abandonment of the area by many people who refused to return even after the incidence had been dealt with, thereby, slowing down the pace of development in the area. Therefore, kidnapping incidence in any given area affects the populace psychologically, socially, economically, developmentally and demographically.

However, the issue of security has been said to be the responsibility of all and sundry as the government alone cannot deal with criminals that threaten the security of any community. The findings of this study reveal that the community itself took up the responsibility of dealing with the menace of kidnapping through its Community Development Association. The CDA was able to alert the State and Local government as well as the nearest police authorities, with committed cooperation with the security agents that were deployed to the area. The response of the state government shows that it is committed to the security of lives and property in the state. The problem of kidnapping was effectively dealt with due to the combination of community and government efforts. Therefore, the menace of crime can best be stemmed down in the country through community policing.

Moreover, the studied community has been able to put in place measures to ensure that kidnapping and other serious criminal activities do not overtake the community in the future by employing night guards and vigilantes. Given the fact that police is yet to have a post or station in the area, the community employed informal policing as the practice in most urban communities in Lagos. This connotes the importance of the informal policing agents in complimenting the efforts of the formal policing apparatus.

\section{CONCLUSION AND RECOMMENDATIONS}

The incidence of kidnapping is a reality in Nigeria like every other serious crime and the fact that urban sprawls are vulnerable to the crime is evident in many of the kidnapping incidence in Lagos state. Kidnappers take advantage of porous security condition of urban sprawls to carry out their nefarious activities which has a serious effect on the security of lives and property of the people. Given the findings of this study, the following are therefore recommended as ways of ensuring security of lives and property in our urban sprawls.

1. There is a need for the establishment of police post or station in the urban sprawls in the state in order to curb the activities of criminal groups.

2. The operation of Lagos state neighbourhood watch should be extended to the urban sprawls in the state as this will aid security and surveillance in the sprawls.

3. Community policing should be taken more serious by the government.

4. The government should embrace all inclusive policing system that integrates the community, formal policing agents and the informal policing agents in both the cities and the sprawls. This will make it difficult for criminals to operate in any area.

\section{References}

Global Kidnapping Review (2016). Crisis Prevention and Response. NYA International. Retrieved (1/2/2018) from www.nyainternational.com 
Illechukwu L.C, Uchem R. and Asogwa U. (2015). Stemming the Incidence of Kidnapping in the Nigerian Society: What Religious Education Can Do? Journal of Culture Society and Development. Vol. 12, pp. 28-47. Retrieved (2/10/2017) from www.iiste.org

Immigration and Refugee Board of Canada (2014). Nigeria: Kidnapping for Ransom, including Frequency, Profile of Victims and Kidnappers; Response by Authorities. NGA104917.E. Retrieved (28/9/2017) from http://www.refworld.org/docid/546dc1724.html

Inyang J.D. and Ubong E.A. (2013). The Social Problem of Kidnapping and Its Implications on the Socio-Economic Development of Nigeria: A Study of Uyo Metropolis. Meditteranean Journal of Social Sciences. Vol. 4, No. 6, pp. 531544, July. Doi:10.5901/mjss.2013.v4n6p531

NewsAdmin (2013). Kidnapping: Nigeria Fastest Growing Industry! The Street Journal. Retrieved (28/9/2017) from www.thestreetjournal.org

Ngwama J.C. (2014). Kidnapping in Nigeria: An Emerging Social Crime and the Implications for the Labour Market. International Journal of Humanities and Social Science. Vol.4, No. 1, pp. 133-145, January. Retrieved (13/8/2016) from www.ijssnet.com

Okoli A. and Agada F.T. (2014). Kidnapping and National Security in Nigeria. Research on Humanities and Social Sciences. Vol. 4, No. 6, pp.137-146.

OSAC (2017). Nigeria Crime and Safety Report: Lagos. Washington D.C, Overseas Security Advisory CouncilBureau of Diplomatic Security.

Ottuh P.O.O and Aitufe V.O. (2014). Kidnapping and Moral Society: An Ethico-Religious Evaluation of the Nigerian Experience. European scientific Journal. Vol. 10, No. 14, pp.420-434, May.

Ukoji V.N and Okolie-Osemene J. (2016). A Study of Crime Reporting in Nigeria. Retrieved (10/2/2018) from www.nigeriawatch.org 